\title{
Chapter 7 \\ The Role of Higher Education Institutions in Development of Social Entrepreneurship: The Case of Tallinn University Social Entrepreneurship Study Program, Estonia
}

\author{
Katri-Liis Lepik and Audronė Urmanavičienė
}

\begin{abstract}
The purpose of this chapter is to introduce a higher education social enterprise program and explore how it is shaping the field of social entrepreneurship. Social enterprise related university programs are an emerging trend. Entrepreneurial university theory and ecosystem framework are used to illustrate how the university social enterprise program, in turn, develops the field of social entrepreneurship. An example of an existing social enterprise program is discussed to highlight how it can be designed. Cases of social enterprises emerged as the result of the program are used to outline the different impacts that such support to social entrepreneurship might have. The research chapter reveals the multi-dimensional nature of the social enterprise program and its impact on students establishing their own social enterprises. It suggests that the incubation and other support activities should expand beyond the university program including a variety of network partners. The chapter provides empirical evidence of social enterprise development in a higher education institution and contributes to the global body of knowledge about fostering social enterprise development. As the provision of social entrepreneurship education is new in Estonia and the discussions on social enterprises are premature, the number of social entrepreneurship development partners is limited and hence the empirical data is currently scarce. The journey towards an entrepreneurial university is limited due to the lack of legal support and suitable infrastructure which would enhance project-based learning, support 'spin-offs' and patenting and rather engenders a more traditional academic learning environment.
\end{abstract}

Keywords Social enterprise $\cdot$ Social entrepreneurship $\cdot$ Higher education institutions $\cdot$ Social enterprise program

K.-L. Lepik $(\bowtie) \cdot$ A. Urmanavičienè

School of Governance, Law and Society, Tallinn University, Tallinn, Estonia

e-mail: kllepik@tlu.ee; aurmana@tlu.ee

C. Păunescu et al. (eds.), Social Innovation in Higher Education, Innovation,

Technology, and Knowledge Management,

https://doi.org/10.1007/978-3-030-84044-0_7 


\section{The Key Points of the Chapter Are the Following}

- To explain the concept of an entrepreneurial university and the social entrepreneurship ecosystem.

- To gain an understanding of social entrepreneurship and its ecosystem in practice based on a country's example.

- To understand how higher education institutions can design a social entrepreneurship master's program.

- To clarify how students are involved in practical project-based learning in the social entrepreneurship program.

- To identify practical learning for higher education institutions from the social entrepreneurship program and how they can be best implemented.

\section{Introduction}

Social entrepreneurship can contribute simultaneously to economic growth and to social and environmental sustainability (OECD, 2020). Higher education institutions (HEIs) are very relevant for the economics of their local environment and have a significant economic and social impact on their communities. The importance of HEIs to take over more societal functions besides their tasks as an academic institution (teaching and research) has increased over recent decades (Domanski et al., 2019). HEIs train employees for the public and private and third sectors and play a major role in tackling social and economic challenges. However, many universities continue to ignore social, economic, environmental and practical challenges in different regions and fail to take an active role in driving social change in the communities. Despite many projects and research, there is still an urgent need to create a better understanding of new processes, skills and tools that are required to exploit the knowledge coming out of universities more effectively and to drive the social entrepreneurship agenda. For social entrepreneurship to flourish, new methods and practices need to be adapted and created in HEIs.

In Estonia, entrepreneurship education is an essential component of the country's vision of an innovative society. It is also part of a broader objective to raise employment levels and create a more inclusive labour market, more particularly to include young people not in employment, education or training. In 2018 Tallinn University (TLU) launched its Social Entrepreneurship Master's Degree programme, which provides participating students with the opportunity to develop their own ideas and projects. The Social Entrepreneurship Master's Degree programme is very new and innovative therefore there is a shortage of data on how this program impacts on the development of the Estonian social entrepreneurship field. The University's role in social entrepreneurship development has been analysed by Păunescu et al. (2013), British Council (2016), Cinar (2019). The social entrepreneurship ecosystem in Estonia has been explored by Reimann (2019), OECD (2020). However, social entrepreneurship education in HEIs is a new phenomenon in Estonia, which is why there is a significant lack of research in this field. This chapter explores the University's and social entrepreneurship study program's roles in the development of the social entrepreneurship field in Estonia. Using a 
single case study design that relies on semi-structured interviews with SE ecosystem participants and a survey of the Tallinn University Social Entrepreneurship MA study program (SEMA) students.

The rest of the chapter is organised as follows. The next paragraphs will analyse literature review on entrepreneurial universities and the social entrepreneurship field in Estonia. The second paragraph will describe methodology adopted by the researchers and design of the Social Entrepreneurship Master program. The third section will reveal the main results of the study. Additionally, the fourth paragraph will present discussion. Finally, the last section will conclude the chapter.

\section{HEIs' Role in the Social Entrepreneurship Field Development}

\subsection{The Role of HEIs in Social Entrepreneurship Processes}

There is a lack of consensus on the definition of an entrepreneurial university (Pugh et al., 2018). According to Urbano and Guerrero (2013), an entrepreneurial university needs to become an entrepreneurial organization, its members need to become entrepreneurs, and its interaction with the environment needs to follow an entrepreneurial pattern. Kirby et al. (2011) state that entrepreneurial university is a natural incubator that, by adopting a coordinated strategy across critical activities (e.g., teaching, research and entrepreneurship), tries to provide an adequate atmosphere in which the university community (e.g., academics, students and staff) can explore, evaluate and exploit ideas that could be transformed into social and economic entrepreneurial initiatives. Audretsch et al. (2012) stress that the role of universities should be more than generating technology transfer (patents, spin-offs and start-ups), and rather, contribute and provide leadership for creating entrepreneurial thinking, actions, institutions and entrepreneurial capital. However, many scholars (Trippl et al., 2015; Pugh et al., 2018; Budyldina, 2018; Thomas \& Pugh, 2020) highlight that the entrepreneurial university is first and foremost a regional actor. According to Sánchez-Barrioluengo and Benneworth (2019), it is increasingly common to claim that driving regional development represents a new 'third' mission for universities alongside the first (teaching) and second (research) missions.

Policymakers all over the world see universities as central actors in regional innovation and development. Universities can play direct and indirect roles in regional development. Pugh et al. (2018) states that universities can play a direct role in developing a regional strategy and working directly with government and policymakers. They are solving regional social and economic problems, promoting innovations through projects, research or work as a knowledge spill-over channel through dissemination of new knowledge and information. Olo et al. (2020) note that their active role in regional development can be in commercializing their knowledge through spin-offs, patents and licensing. Regions in this way profit through job creation, spin offs, knowledge spill-overs, attraction of new talents, and research that 
may be translated into products and services. Thus, HEIs can impact economic wellbeing and foster innovations in the region.

Other scholars (Budyldina, 2018; Sánchez-Barrioluengo \& Benneworth, 2019) emphasize HEIs' indirect role in the regions by promoting entrepreneurial culture (organizing forums, conferences and workshops, and entrepreneurship courses), taking advisory roles, offering consultancy and industry training, and being willing to collaborate with regional industry and policymakers, are required to capture the entrepreneurial potential of a university. In their research, Thomas and Pugh (2020) noted that the entrepreneurial university concept should go beyond its purely economic roles as a key deliverer of support and services to local populations. The entrepreneurial university concept should incorporate socially oriented ideas such as social innovation and social entrepreneurship thinking: "universities need to be a positive force for social good in their regions" (Thomas \& Pugh, 2020).

However, it is still important to emphasize that among scientists, entrepreneurs, and politicians there are very different understandings about what social entrepreneurship means and addresses (Cagarman et al., 2020). According to Volkmann et al. (2018), social entrepreneurship is still looking for its identity; its conceptual limits have not yet been reached and there is no common concept. In order to understand this phenomenon, it is appropriate to single out the features that characterize social entrepreneurship. Based on the scientific literature (Volkman et al., 2012; Defourny \& Nyssens, 2012), the following main features of social entrepreneurship can be mentioned: social value creation/social mission; market orientation; innovation creation. Social mission is a highly valued aspect of social entrepreneurship, which is undoubtedly considered a prerequisite for social entrepreneurship. Social entrepreneurship is primarily about social value creation, building social wellbeing, solving social problems and addressing social needs. Market orientation is another integral aspect of social entrepreneurship. The market orientation of social entrepreneurship is often associated with companies' commercial activities, financial sustainability and autonomy. Social innovation is also an important aspect of social entrepreneurship. Social entrepreneurs are seen as innovators, driving important social change. Innovation can be implemented through innovative or improved products and services creation or through the formation of new thinking, new or improved social problems solutions. Thus, social entrepreneurship can be understood as one such potential mechanism where actors create new forms of social organizations, structures and institutions that help solve social and environmental challenges (Cinar, 2019).

There are discussions about what HEIs' role in social entrepreneurship processes should be. Different authors emphasize various aspects of HEIs engagement in social entrepreneurship development. García-González and Ramírez-Montoya (2021) point out that HEIs have increasingly been engaged in promoting education for social entrepreneurship. In recent years, several trends and pedagogical practices for social entrepreneurs' training have emerged. Many HEIs take importance to the development of interdisciplinary profiles in social entrepreneurship students, providing them with opportunities to develop innovative social entrepreneurship competencies. Educational experiences directed to social entrepreneurship are based on 
active learning practices. Students face real-world challenges, linking theoretical reflection to a transaction experienced in the environment. Roslan et al. (2019) emphasizes that HEIs can also assist by acquiring the resources needed to create the environment that can strengthen the relationships between students and social entrepreneurs. The learning process is important so that the students can practice their experience, knowledge and skills even after their post-graduation. The role of the institution is needed in preparing the future social entrepreneur with high motivational support.

According to Benneworth and Cunha (2015), the university contributes to social entrepreneurship processes in these ways: providing knowledge which helps progression between the stages in helping move the process forward, either as piece of existing knowledge or something co-created with the affected community; making its resources available, whether providing direct financial support or providing access to university infrastructure and assets in the innovation process; supporting the social entrepreneurship, either through advising social entrepreneurs how to access external knowledge resources, or persuading others to support social entrepreneurship. Kim and Fuessel (2020) point out that HEIs need not just to support the progress of social entrepreneurship, but also to embed changemaking into their culture, operations, and educational offerings. They need to be increasingly prepared to deploy their tremendous human capital—as well as knowledge and research assets-in trans-disciplinary, collaborative, and innovative ways to address the many challenges ahead. They need to co-create world-changing knowledge and impact within their community. They have to be able to respond quickly to community and region needs. Thomas and Pugh (2020) note that HEIs are facing pressures to generate solutions to economic and social problems in order to increase their impact on the regional communities. The university contribution to social entrepreneurship can be characterized as one of the many third mission activities through which universities can reach out to civil society (Cinar, 2019) by knowledge creation and exchange within community, partnerships with civil society etc. (Păunescu et al., 2013). Thus, entrepreneurial universities should be viewed as a rebuttal against each point in a broader perspective and taking into account their contribution to social entrepreneurship development as well. However, HEIs contributions to social entrepreneurship development should be addressed holistically taking into account analysis of regional communities' problems and the environment within which they function.

\subsection{Social Entrepreneurship Field in Estonia}

Social entrepreneurship field in Estonia is quite small compared to other countries in the EU (European Commision, 2020). There are about 121 social enterprises (Reimann, 2019), however this data is not accurate, because many enterprises with a social and or environmental mission do not define themselves as social enterprises. The majority of officially recognised social enterprises (93\%) are non-profit 
organizations operating in the human health and social sectors or in education. Most are located in the two largest cities (the capital city, Tallinn, in the north and Tartu in the south) and are typically small organisations (one to four persons). About $40 \%$ of non-profit social enterprises help people with reduced work ability, focus on their rehabilitation and support their daily well-being.

An additional, key target group is children and the elderly. About one fourth are engaged in providing self-development opportunities and hobby activities, offering new skills to parents or raising the natural environment awareness of school children. A significant number of organisations are active as community centres (including the provision of free time activities) for local people. These organisations also promote tourism, environmental protection and sustainable consumption, the provision of cultural activities or participation opportunities. Several combine the provision of diverse activities, including for instance cultural activities and tourism services.

Social enterprises have very slowly emerged over the past years. The debate about their legal status is still sluggish (Reimann, 2019). There are issues that create difficulties for social enterprises, such as the financing which is clearly dependent on the legal form the social enterprises have chosen, the lack of a broader political support, the lack of private investments into social enterprises and inadequate recognition by the wider public. The obstacles for social enterprise development in Estonia are rooted in the historical context where the term "social" is still associated by the wider public with either socialism or the planned economy of the Soviet period or social services as being of poor quality or underdeveloped (OECD, 2020).

Despite all these challenges, the Estonian start-up scene is very advanced (OECD, 2020). There are a large number of development programmes for start-ups and regular hackathons where social enterprises can participate regardless of their status. The sustainability topic is increasing within enterprises and start-ups. Also, millennials are more and more eager to make a positive impact in society, be environmentally and socially responsible. Thus, there are many opportunities for social entrepreneurship development in Estonia. The future perspectives of social entrepreneurship field development in Estonia strongly relies also on educating the newer generations about social enterprises and their social impact. Additionally, on building a strong ecosystem of social entrepreneurship. There are more and more actors who are working to promote social enterprises in Estonia. These stakeholders will be presented in the next section.

\subsection{Main Actors in Social Enterprises’'Ecosystem}

The social enterprise ecosystem is characterized by complex interactions among a variety of stakeholders (actors) and their components, and the ecosystem aims to support social enterprise (SE) development. The ecosystem concept provides a complete framework for socio-economic development, in which actors with diverse backgrounds and perspectives collectively work to improve the environment to make it favourable to social entrepreneurs (Kumari et al., 2020). HEIs usually play 
an important role in promoting the culture of trust and learning that reduces the conflict between partners. The knowledge exchange between HEIs and the community in the social entrepreneurship field brings positive change in society and promotes social enterprises.

Key players in the Estonian social entrepreneurship ecosystem include the Good Deeds Foundation, National Foundation of Civil Society (NFCS), several public bodies; the umbrella organisation) Estonian Social Enterprise Network (ESEN); and business incubators which include social enterprises. ESEN has impacted the SE ecosystem in various ways for example by reviewing corporation law and lobbying for social enterprises (Reimann, 2019). The revision includes legislation covering legal bodies and a systemic analysis of legislative harmonisation and updating. It has determined the criteria for social enterprises within an Estonian context, undertaken consultation and provided expertise regarding the inclusion of volunteers in social enterprises. ESEN has successfully introduced social entrepreneurship development ideas to Estonian policy documents.

The main support organisations promoting and supporting social enterprises in Estonia are the NFCS and the Good Deed Foundation. The NFCS is one of the main funders of Estonian social enterprises (National Foundation of Civil Society, 2021). It provides project-based support to a large variety of social enterprises, both on national and community level and in a start-up phase and in an already more mature phase. The Good Deed Foundation's Impact Fund (Good Deed Foundation Impact Fund, 2021) is a very recent development. Although the fund targets high-impact organisations that can be scaled up whether they are social enterprises or not, the foundation views its fund as a strategic initiative that in the long-term will help prepare investment-ready organisations.

The NULA incubation program (Nula incubator, 2021) for the last 3 years, supported by the NFC, has been helping highly motivated teams improve skills to develop new ideas and sustainable solutions for social problems. The incubation program is based on different business incubation models around the world, including the development and incubation programs of Impact Hub and Estonian start-up support programs. It consists of expert training sessions and lean prototyping. Ajujaht is the only competition that finances social enterprise start-ups (Ajujaht accelerator, 2021). The main Estonian business idea competition, Ajujaht, recognises social enterprise start-ups in a separate category in collaboration with the SEB bank and NFCS. Social enterprises have advanced their ideas over the years and competition has grown.

The Ministry of Social Affairs and the Ministry of the Interior are the public sector players whose development plans are closely linked to social enterprises (OECD, 2020). The Ministry of Social Affairs has a development plan addressing social challenges and goals, including reducing inequality and poverty, improving quality of life and health. The Ministry of Interior has completed the Civil Society Program 2021-2023 clearly aiming at capable civil society organisations and social enterprises.

Research and educational programmes focus on social innovation or entrepreneurship rather than social entrepreneurship. Currently, the Ministry of Education 
and Science leads the entrepreneurship programme Edu and Tegu (2016-2020), which aims to promote and enhance an entrepreneurial mindset and entrepreneurship in schools at all levels. It has created an entrepreneurship education programme for vocational schools and universities. One of its modules specifically addresses social entrepreneurship. The programme is being piloted in Estonian higher education institutions. The following universities have Social Entrepreneurship Development courses: Tallinn University, the Estonian Business School, Tallinn University of Technology, Tartu University. Tallinn University has a special master's degree programme in social entrepreneurship, which it launched in 2018. It focuses on project-based learning providing knowledge and support for students to establish their own social enterprises. Junior Achievement Estonia (Junior Achievement Estonia, 2021) runs entrepreneurship programmes for high school students that not only aims to equip them with entrepreneurial skills but also helps create enterprises, including social enterprises. The programme also supports teachers. Another educational programme 'Entrepreneurial School' supports the development of entrepreneurial skills in high schools. In 2018 a new Economy Study Book was published with a separate chapter on social entrepreneurship. Changemakers Academy (Changemakers Academy, 2021) launched competition for high school students encouraging them to develop their own social enterprise ideas with mentors. The social entrepreneurship competition is run in cooperation with the British Council. It supports multilingual high school students to create their first social enterprise marketing concepts.

Thus, despite a broad range of activity (see Fig. 7.1) and dynamic players, Estonia is still in the process of developing a social enterprise ecosystem. The sector, as a whole, still lacks general political and public support. There are in development numerous key policy documents where social enterprise features although there is no one cohesive social enterprise framework. Funding for social enterprises in Estonia has come mainly from public sources. Moreover, there are many educational programs which are focusing on high school students and their social project ideas. HEIs are mostly promoting social enterprise education and training, but still their main focus remains on entrepreneurship rather than social entrepreneurship. However, there is a lack of information about HEIs and other players' cooperation for social entrepreneurship development in Estonia. And what are the HEIs' role in the SE field development behind social entrepreneurship education.

\section{The Case Study Approach}

\subsection{Case Study Research Design}

A case study approach aims to understand a wider context by interpreting the actions of a single group, community or a single event, meaning a case. Gillham (2000) defines a case study as an investigation to answer specific research questions which seek a range of different evidence from the case settings. If the researcher only wants 


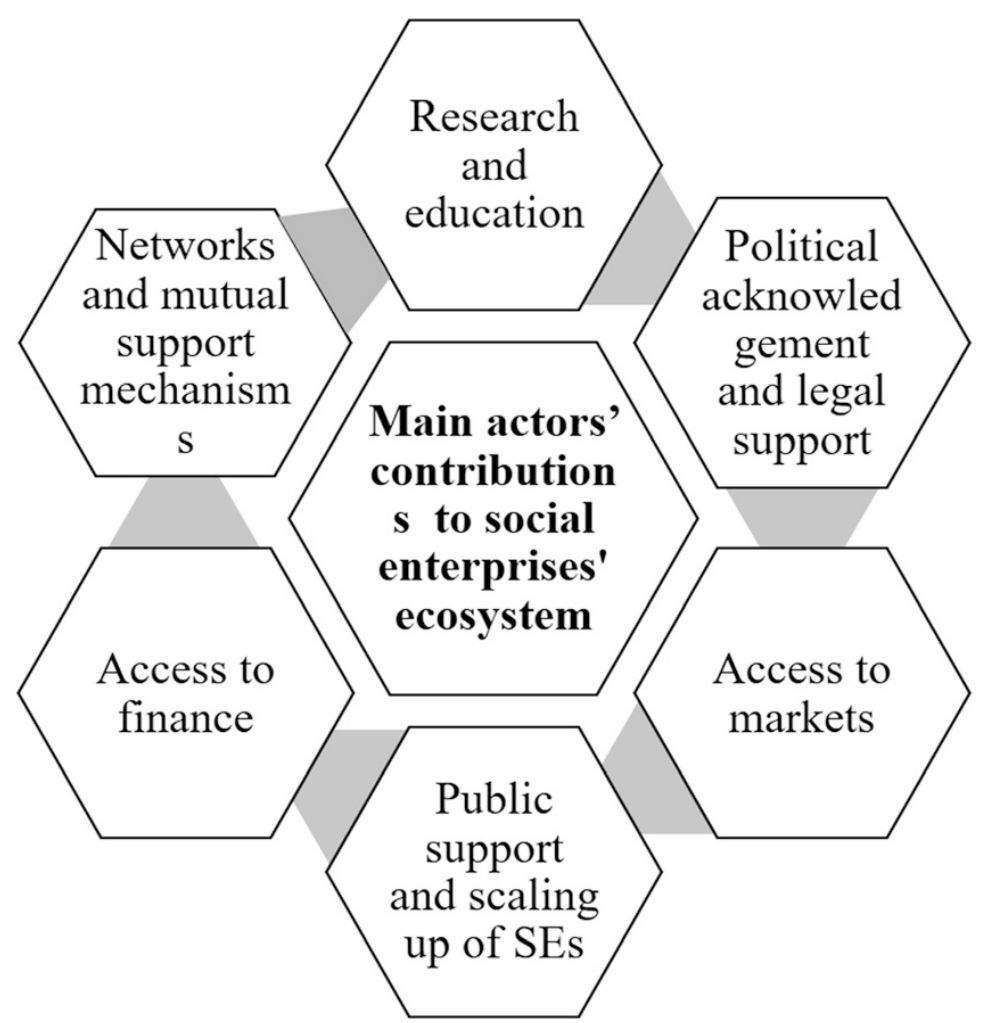

Fig. 7.1 Main actors' contributions to social enterprises' ecosystem. Source: Authors

to study one single thing or a single group, a single case study is the best choice (Yin, 2003). When a single case study is used, it helps the researcher to get a deeper understanding of the subject. The analysis of one case also helps to create theoretical constructs and/or propositions from the empirical evidence provided by the case (Yin, 2003). Therefore, the process of theory building through this methodological approach is inductive, i.e., the theory emerges as patterns of relationships between constructs are recognized in the case and between cases (Yin, 2009).

The case study focuses on Tallinn University Social entrepreneurship master study program. Social entrepreneurship study program was studied in order to get a more in-depth understanding about the topic under discussion through case study design. The research was conducted by interviewing SEMA's program stakeholders and SEMA students. Data for this study was collected in September-October 2020 with the aid of a semi-structured interview guide (Creswell, 2009). Semi-structured interviews were conducted with SE field participants for a deep understanding of this phenomenon. Research participants are representatives of 6 active organizations in social entrepreneurship scene and they have a good knowledge about SE field in Estonia. The researchers have the authority to determine what needs to be known and 
Table 7.1 Codes and information about institutions

\begin{tabular}{l|l}
\hline Code for the Interviewee & Institution \\
\hline R-1 & Social enterprise network \\
\hline R-2 & Open academy \\
\hline R-3 & Võru municipality \\
\hline R-4 & Stories for impact organization \\
\hline R-5 & STARTERtallinn \\
\hline R-6 & Tallinn City Enterprise department \\
\hline
\end{tabular}

find the people who are willing to provide information according to their knowledge or experience. Thus, semi-structured and open-ended interview questions were formed to conduct interviews. Interview research questions included: (1) What do you think is the role of HEIs in social entrepreneurship development and support in Estonia? (2) How TLU (SEMA program) impacts social enterprise field development in Estonia? (3) Why do you think the project-based learning is important for Estonian social entrepreneurship field development? Table 7.1 presents the information about interviewees. The methodology of qualitative research recommends that the respondents choose whether to remain anonymous or to publish their names (Kaiser, 2009). Depending on the request of many respondents, the names of the respondents are not provided, and when quoting the respondent's statement, his/her number is indicated (Table 7.1).

Additionally, an online survey was conducted during November 2019 among SEMA students in both cohorts (first year and second year students) collect feedback from SEMA students about the SEMA program and ask them about their motivations and plans. 28 students of 31 had participated anonymously in the online survey. Descriptive statistics was used to analyse the data obtained from quantitative research. The data collected during the quantitative survey were processed with the Excel program.

\subsection{Design of the Social Entrepreneurship Master's Program}

The Tallinn University Development plan for 2020-2022 (Tallinn University, 2020) promotes social innovation. According to this plan, the university should render meaning to the relationship between local communities and the state in the context of sustainable society and digital era practices to support the evolution of new forms of collective activity, and to develop solutions for increasing the cohesion and responsibility of communities. Also, the university undertakes, in cooperation with enterprises and other organizations, to promote social entrepreneurship and creative entrepreneurship networks. Tallinn University is the only university that has a curriculum for Social Entrepreneurship in the Baltic region. The Social Entrepreneurship programme is a progressive educational initiative of Tallinn University with the aim to promote entrepreneurship and the innovation of the social and health sector, environmental protection, urban development, rural development and 
7 The Role of Higher Education Institutions in Development of Social...

Table 7.2 SEMA students' social entrepreneurship projects examples

\begin{tabular}{l|l|l|l|l}
\hline $\begin{array}{l}\text { Projects } \\
\text { names }\end{array}$ & Field & Main goal & Product/Service & $\begin{array}{l}\text { Impact } \\
\text { measurement }\end{array}$ \\
\hline Koos & $\begin{array}{l}\text { Local } \\
\text { Community }\end{array}$ & $\begin{array}{l}\text { Support the local } \\
\text { community and } \\
\text { gather people around } \\
\text { a common idea }\end{array}$ & $\begin{array}{l}\text { a local cafe, which rev- } \\
\text { enues are used to sup- } \\
\text { port community } \\
\text { projects }\end{array}$ & $\begin{array}{l}\text { Number of mem- } \\
\text { bers of KOOS cafe } \\
\text { and number of } \\
\text { projects supported }\end{array}$ \\
\hline $\begin{array}{l}\text { Loomro } \\
\text { Onnnelik } \\
\text { faces }\end{array}$ & $\begin{array}{l}\text { Disabled } \\
\text { fashion }\end{array}$ & $\begin{array}{l}\text { Empower differently } \\
\text { able people and } \\
\text { unleash their creativ- } \\
\text { ity inspired by art }\end{array}$ & $\begin{array}{l}\text { Selling hand-printed } \\
\text { organic cotton t-shirts, } \\
\text { which revenues are } \\
\text { used for art education }\end{array}$ & $\begin{array}{l}\text { Investments in art } \\
\text { education }\end{array}$ \\
\hline Superable & $\begin{array}{l}\text { Goal is to keep the } \\
\text { elderly active and } \\
\text { feel meaningful in } \\
\text { their daily life }\end{array}$ & $\begin{array}{l}\text { Workshops for elderly } \\
\text { people, selling products } \\
\text { created by elderly } \\
\text { people }\end{array}$ & $\begin{array}{l}\text { lives, feedback } \\
\text { from the elderly }\end{array}$ \\
\hline $\begin{array}{l}\text { Peopled } \\
\text { Banned }\end{array}$ & $\begin{array}{l}\text { Support people with } \\
\text { special needs and } \\
\text { develop or maintain } \\
\text { their skills }\end{array}$ & $\begin{array}{l}\text { Training services and } \\
\text { workshops }\end{array}$ & $\begin{array}{l}\text { Job places created } \\
\text { for disabled }\end{array}$ \\
\hline
\end{tabular}

community development (Social entrepreneurship study program, 2021). The curriculum gives not only an academic degree but also a supportive environment for development. The program follows the project-based learning method. Project Based Learning as a teaching method allows students to gain knowledge and skills by working for an extended period of time to investigate and respond to a complex question, problem or challenge. Experienced staff members of Tallinn University guide students through their learning process in a very practice-oriented way using the academic and creative infrastructure of Tallinn University for both academic learning and development. The program follows the interdisciplinary approach, including interdisciplinary project courses, which broaden perspectives. Students in the SEMA program are encouraged to develop their social entrepreneurship projects on regional and global problems solving and present to many stakeholders in different regional events, such as Digital Innovation Days Hackathon, Tallinn Startup Week and the STARTERtallinn program. Table 7.2 shows SEMA students' social entrepreneurship projects which were established in Estonia since 2018 and were focused more on regional problems.

The first project in Table 7.2 is KOOS Café \& Foundation. The primary tool for KOOS Foundation is to support the local community and gather people around a common idea to be a local cafe. The KOOS Cafe is a source of encouragement and support to the local community. The cafe goal is to bring together members of the society around a common idea of helping their local community. The second is LOOMRO social enterprise which is based in Tallinn. Under the brand name "LOOMRO" they sell hand-printed organic cotton t-shirts. They use drawings of 
differently abled artists as artworks of their products. LOOMRO uses organic cotton garments that are bought from traditional organic cotton manufacturers in Bangladesh and they use eco-friendly hand printing methods to print artworks. They strive to raise awareness about differently abled people and become a global leader in unique fashion brands. Onnelik Faces is a project focusing on the elderly in society. There is a growing ageing population in Estonia, so their goal is to keep the elderly active and feel meaningful in their daily life. In this project, they engage the elderly from different aspects. For elders who have skills to make products, they assist them to improve and sell their products. For the elders with limited physical strength, they design light activities for them, for example making wrapping paper or caring for plants, which can then be sold through the business part of the project. They also design their own products and invite the elderly to produce them. The next project is Superable. This is a project for people with special needs, supporting them to maintain their skills and develop new ones. They pave the way for every person to show their full potential and to gain access to a better and easier life. The aim is to create a safe and professional environment where everyone feels welcomed and comfortable to speak up. They organize various workshops, webinars, events, where the focus is self-growth and self-development, professional skills. The Banned books museum is a cultural hot-spot in the old-town of Tallinn for people interested in freedom of expression. The collection holds over one-hundred books that are/were banned all over the world. At the location they host events, book clubs, and interviews. With the museum, they want to raise people's awareness of the long history of censorship and the importance of freedom of speech. Freedom of thought and expression is not a universally accepted human right to this day. They contribute to the dissemination of freedom of speech with the museum. All projects which were presented above are very unique and different in their size, aims, target groups and business models, but all of them are focusing on real social problems solving and how to create a bigger social impact in Estonian society and beyond.

Social entrepreneurship in higher education can help the students to extend their networks with many other social entrepreneurs by using the ticket of a university platform. It can as well help to provide a potential and great business sustenance by engaging in collaborations to give more practical skills, experiences, and insight of social entrepreneurship itself (Roslan et al., 2019). Recent research on social entrepreneurship education indicates that cross organizational cooperation is an important trend in the cultivation of social entrepreneurship talents. For example, Bazan et al. (2020) point out that the integration of the external environment and college initiatives play an important role in promoting students' social entrepreneurship learning. Some scholars also pointed out that the construction of college students' entrepreneurial environment will help to enhance students' social entrepreneurial willingness. In addition, García-González and Ramírez-Montoya (2019) believe that the construction of school, government, society, and enterprise-four spiral cooperation projects-will help to cultivate students' social entrepreneurial and innovation ability.

According to Roslan et al. (2019), there is also a need to create more awareness about the social entrepreneurship curriculum and combine the innovative solutions 
to solve the social problems. Thus, SEMA lecturers and other experts created a remote incubation program for social entrepreneurs (Social Entrepreneurship Incubator, 2021). These services are available not just for the university students, but also for social entrepreneurs and experts from all over the world. Extending the networking opportunity and development work to a global perspective which is an important character of the Estonian entrepreneurship field and now it is also available for social entrepreneurs through this initiative. The incubation aim is to guide participants through a proper business development model designed for social enterprises and validate their social entrepreneurial ideas (Social Entrepreneurship Incubator, 2021). During the validation process they help participants to work on product-market fit, clarify intellectual property issues, and build up a support network for the implementation. The participants can use the service of mentors and experts from university program and can get direct feedback. Another important profile of the incubation program is the international networking opportunity to help social entrepreneurs in scaling up their local initiatives to an international level.

As the competition between universities increases, universities need to create better connections with the communities where they are located and operate, and constantly supply added value to all their stakeholders (Paunescu \& Cantaragiu, 2013). Designing courses considering the characteristics of the regions, planning some of the academic and social events with local residents of the cities, and aligning student projects with regional needs are some examples. Initiatives should go beyond enabling only a small segment of students to undertake internships in regional organisations and should incorporate university-region interaction into teaching and research (Goddard et al., 2016). The demand for universities to have more engagement with local governments and businesses is rapidly increasing (Roslan et al., 2019).

The Social Entrepreneurship programme is active in organizing forums, conferences and workshops, involving academic staff, students and various stakeholders in entrepreneurial activities in Estonia and abroad. One of the ongoing projects is the co-creation of innovative services in Europe. SEMA has organised social hackathons and development days where people with special needs develop their own ideas. One example is the European Union (EU) project Co-creation of Social Service Innovation in Europe (CoSIE) that was carried out in one region of Estonia-Võru county (CoSIE project, 2021). The CoSIE project (2021), as an international consortium and aims to introduce innovative social service development. Võru County is a rural area situated in southern Estonia. Hackathons are one of the core methods of the start-up scene for giving a kick-start to ideas guiding them to pre-incubation, incubation and elevation (Toros et al., 2020). The hackathon as a method was developed within the start-up scene. For example, hackathons have helped to bring together support persons and people with special needs. Tallinn University's role was to support the development of such ideas and to help them come up with a business model. The social hackathon helped to mobilize community resources including lessempowered groups in a remote area in Võru County, Estonia. The hackathon was organized in cooperation with the Võru municipality. Municipalities in rural areas compared to urban areas cannot provide services equally for everyone in the sparsely 
populated areas. There is a need for alternative solutions and tailor-made services for those user groups whose needs cannot be met with standardised services, such as transportation services and home care for elderly (Toros et al., 2020). According to Eurostat (2015), Estonia ranked well below the EU average in terms of social protection expenditure per capita. As a result, mobilising community resources that compensate for a state-financed welfare system is particularly important.

The inter-disciplinary projects or ELU (Enhanced Learning Unlimited) projects are a compulsory element in every student's curriculum during their studies at Tallinn University (Tallinn University Development Plan, 2020). An important element of Project Based Learning is that students make their project work public by explaining, displaying and/or presenting it to stakeholders outside the classroom (Blumenfeld \& Krajcik, 2006). In order to gain feedback from the external stakeholders, the inter-disciplinary project was taken to a social hackathon in Võru where the project idea was validated together with local private sector, public sector and community sector stakeholders along with Tallinn University and international students as part of the team. The hackathon ideas contributed to social inclusion of vulnerable people in the region on the level of local communities. The format of the work was co-creation. Co-creation refers to the active involvement of end-users in various stages of the production process (Voorberg et al., 2015). In this particular hackathon the stakeholders were local government representatives, service providers, and user groups, but also entrepreneurs, community leaders and fellow citizens. The hackathon as a development event is well known from within the IT sector. In Estonia, this multi-disciplinary innovation approach is extended to the welfare system, too. By bringing together people with diverse backgrounds, experience, and expertise in a single location over short periods of time, hackathons support intensive bursts of creativity. The diverse skills of participants can facilitate innovation and learning due to participants being able to generate and assess ideas from various perspectives. Therefore, hackathon events can be useful for developing solutions within the community.

Moreover, Tallinn University together with other Universities run an extracurricular entrepreneurial business development programme called STARTER (Starter Tallinn Program, 2021). The programme enables students to develop their ideas into recognised business models. The hands-on workshops are integrated with mentoring sessions. Mentors are start-up founders or entrepreneurs from different business sectors. Students can turn their ideas into reality by participating in inspirational events, workshops, meet-ups with entrepreneurs and pitching competitions.

To sum up, the SEMA program covers a wide spectrum of activities including teaching, knowledge and skills development, dissemination of entrepreneurial spirit among students and social entrepreneurs, incubation programs and new social enterprise creation. Tallinn University, through the SEMA program, contributes directly to social entrepreneurship development by organizing social hackathons and helping less-empowered groups in a remote area in Estonia. The program's activities produce new knowledge and initiate social innovations and social enterprises which fit regional needs and expectations. 


\subsection{Survey Results}

At the time of the survey there were 31 students in the SEMA program from which 28 answered online survey questions anonymously. In the survey they were asked about: their main motivation and personal aims in the SEMA program, their opinion and preferences about project-based learning, SEMA courses, and their suggestions about improving the program.

Main Motivation and Personal Aims in the SEMA Program 17 students $(60,7 \%)$ agreed that they wanted to learn about social entrepreneurship. 15 students $(53,6 \%)$ wanted to gain entrepreneurial skills, and 14 students $(50 \%)$ came to implement their own social enterprise idea. Only 5 students $(17,9 \%)$ indicated that their main motivation was to do research on social entrepreneurship. One student made the remark in the "other option" that her motivation was to work on social projects, not necessarily an entrepreneurial one.

Opinions and Preferences about Project-Based Learning According to $19(67,9 \%)$ participating students, the most important elements of project-based learning in SEMA are that students can work on a live development even in the classroom. 15 students $(53,6 \%)$ found it important that they can submit homework related to their real-life projects. 14 students $(50 \%)$ found it important to participate in hackathons and other innovation events. In contrast, there was one student leaving a harsh remark about pitching and participation in hackathons, requiring a more academic style of teaching in the program. 15 students $(53,6 \%)$ responded that they would definitely like to use mentorship opportunities out of classroom courses.

SEMA Courses The SEMA courses contribute directly to social enterprise project development. 22 students $(78,6 \%)$ of SEMA program agree or rather agree with this statement. Only 6 students $(21,4 \%)$ took a neutral position which may be considered a polite disagreement. Vast majority of SEMA students find direct relation between their courses and real-life project development.

Suggestions about Improving the Program There was serious feedback about the classroom burden and the coordination of the development journey beyond courses. There is a clear need for creating a healthier balance between classroom work and project development. Issues of intellectual property rights or communication of projects in social media and the University website were also raised. The SEMA program does not have the proper legal tools (contracts, schemes, insurance opportunities, legal environment for spin-offs and investments) for real entrepreneurial activities, the infrastructure (both physical and legal) of the University serves traditional academic work.

This survey proved that SEMA courses contribute directly to project development, students are actively engaged in their project creation and other activities such as hackathons, innovation events. However, it was found that the program does not have an established environment for spin-offs and investments which also serves to improve the University's ecosystem. 


\subsection{Interviews' Findings}

In order to better understand the impact which HEIs and SEMA program can bring to the Estonian social entrepreneurship field development the interviews were conducted with SEMA's program stakeholders (Table 7.3).

Thus, it can be said that according to respondents HEIs in Estonia can be seen as the organisations who train the people who establish SEs. Furthermore, they are important partners, which can provide knowledge and evidence for the SE entrepreneurship field in Estonia. They can fulfil an advisory role through academic skills and benefit such a partnership through knowledge transfer. The interviews revealed that the SEMA program mostly contributes to the social entrepreneurship field (see Table 7.3) through educating future social entrepreneurs, building linkages between academia and SE organizations, and practitioners. Also, SEMA helps to promote social entrepreneurship in Estonian society and provides cooperation for national and international SE projects development.

\section{Discussion and Conclusions}

The SEMA program educates future social entrepreneurs, teaches them how to solve real life problems and understand the needs of the beneficiaries. It helps to build institutional linkages between academia and other sectors and strengthens the role of Tallinn University in the social entrepreneurship field. However, it remains a question to which extent HEIs can be perceived as innovators and entrepreneurial actors themselves. The conducted interviews and analysed documents are positioning Universities to an educational and research role, and majority of Tallinn University's partners were mentioning these dimensions. Project based learning as a very specific approach of the SEMA program has been also rather perceived as an opportunity for students to gain relevant professional skills than a direct entrepreneurial action of the University contributing to the Estonian SE community with new innovations.

The authors have reflected on the development, innovation and creative thinking and in general consider the University as an innovation hub however, this is not the perception that partners have. HEIs have their own path dependency, the shift from traditional academic institutions to the concept of entrepreneurial university is a long process. A further challenge is that even within the University the entrepreneurial direction is far from mainstream despite the ambitious and progressive keywords in the strategic plan. This is still the beginning of the impact journey and there is a constant need to develop the impact measures and then assess the project-based learning accordingly. The SEMA program has a very obvious starting point moving forward in the direction of entrepreneurial university as a direct contributor to innovation and as such the program is a good initiative in that journey. More efforts are needed to demonstrate the impact of SEMA program through spin-offs and 
Table 7.3 HEIs and SEMA program contribution to social entrepreneurship field development

\begin{tabular}{|c|c|c|}
\hline Category & Subcategory & Statements \\
\hline \multirow[t]{2}{*}{$\begin{array}{l}\text { Higher edu- } \\
\text { cation } \\
\text { institutions }\end{array}$} & $\begin{array}{l}\text { HEIs provide research-based input_-ana- } \\
\text { lyse the national/regional context and field } \\
\text { around SE }\end{array}$ & $\begin{array}{l}\text { "It gives data, professionals and } \\
\text { insight which are needed to run a } \\
\text { new mindset inside a country" R-1 } \\
\text { (social enterprise network) } \\
\text { "Providing high-quality research } \\
\text { and forward thinking to advance the } \\
\text { field of social entrepreneurship" R-4 } \\
\text { (stories for impact organization) }\end{array}$ \\
\hline & $\begin{array}{l}\text { HEIs provide knowledge and education in } \\
\text { the social entrepreneurship field in Estonia }\end{array}$ & $\begin{array}{l}\text { "The lectures and debates increase } \\
\text { the awareness of people inside the } \\
\text { HEI and inside the country. As a } \\
\text { result, this can bring forth enter- } \\
\text { prises with an impact-before-reve- } \\
\text { nue mindset which benefits the } \\
\text { people inside the country" R-1 } \\
\text { (social enterprise network) } \\
\text { "HEIs are important partners in } \\
\text { innovation helixes. To be competi- } \\
\text { tive, the field has to be based also on } \\
\text { a scientific and knowledge-based } \\
\text { frame in its activities" R-2 (open } \\
\text { academy) } \\
\text { "As the field of social entrepreneur- } \\
\text { ship is quite new in Estonia, HEI has } \\
\text { a very important role in its develop- } \\
\text { ment. HEI can spread the new con- } \\
\text { cepts through students and projects" } \\
\mathrm{R}-5 \text { (STARTERtallinn) } \\
\text { "Teaching the combination of con- } \\
\text { cepts and skills needed to entrepre- } \\
\text { neurially tackle social and } \\
\text { environmental problems" R-4 } \\
\text { (stories for impact organization) } \\
\text { "Very important, because it repre- } \\
\text { sents both theoretical views and best } \\
\text { practices from around the world, as } \\
\text { well as the practical side, giving } \\
\text { students the opportunity to test our } \\
\text { suitable solutions in various pro- } \\
\text { jects" R-6 (Tallinn City Enterprise } \\
\text { department) }\end{array}$ \\
\hline $\begin{array}{l}\text { Tallinn } \\
\text { university }\end{array}$ & $\begin{array}{l}\text { The knowledge and education partner in } \\
\text { the social enterprise field }\end{array}$ & $\begin{array}{l}\text { "TLU has a very special role to play } \\
\text { in raising the private and public } \\
\text { sector knowledge of future business } \\
\text { models and to be the knowledge and } \\
\text { education partner in the social } \\
\text { enterprise field in Estonia to } \\
\text { strengthen the whole field" R-2 } \\
\text { (open academy) } \\
\text { "TLU can provide a neutral }\end{array}$ \\
\hline
\end{tabular}


Table 7.3 (continued)

\begin{tabular}{|c|c|c|}
\hline Category & Subcategory & Statements \\
\hline & & $\begin{array}{l}\text { platform (partnership) to bring } \\
\text { together many different private and } \\
\text { third sector organisations and build } \\
\text { the linkages between them. Thus, to } \\
\text { some extent it has the facilitator role } \\
\text { in the field. As a university it has } \\
\text { plenty of international connections } \\
\text { with other universities, so it can } \\
\text { bring in external knowledge and } \\
\text { develop relationships also abroad" } \\
\mathrm{R}-2 \text { (open academy) }\end{array}$ \\
\hline \multirow[t]{3}{*}{$\begin{array}{l}\text { SEMA } \\
\text { program }\end{array}$} & Educates the future social entrepreneurs & $\begin{array}{l}\text { Raises experts in the field. SEMA } \\
\text { program transfer the knowledge } \\
\text { from international level to Estonia } \\
\text { and vice versa" R-3 (Võru munici- } \\
\text { pality) } \\
\text { "SEMA also educates the future } \\
\text { social entrepreneurs and through } \\
\text { that it strengthens and expands the } \\
\text { social entrepreneurship field in } \\
\text { Estonia" R-2 (open academy) } \\
\text { "It is a practical approach to learn- } \\
\text { ing and the Estonian social entre- } \\
\text { preneurship field will only benefit } \\
\text { from those kinds of people (gradu- } \\
\text { ates of SEMA program) who have } \\
\text { strong connections with the actual } \\
\text { problems and possibilities". R-2 } \\
\text { (open academy) }\end{array}$ \\
\hline & $\begin{array}{l}\text { Provides cooperation for international and } \\
\text { national projects }\end{array}$ & $\begin{array}{l}\text { "Acts as a role model for the people } \\
\text { driving social entrepreneurship } \\
\text { inside the country, especially } \\
\text { regarding the creation and scalabil- } \\
\text { ity of innovation, provides invalu- } \\
\text { able cooperation on both on an } \\
\text { international and on national basis } \\
\text { for projects" } R-1 \text { (social enterprise } \\
\text { network) }\end{array}$ \\
\hline & $\begin{array}{l}\text { Builds linkages between academia and SE } \\
\text { field organizations }\end{array}$ & $\begin{array}{l}\text { "Project based learning presumes to } \\
\text { connect with the people in the field } \\
\text { and via networking, the students } \\
\text { become active agents in the network } \\
\text { themselves. Furthermore, this again } \\
\text { helps to build institutional linkages } \\
\text { between academia and real life and } \\
\text { strengthens the role of TLU in the } \\
\text { social entrepreneurship field" R-2 } \\
\text { (open academy) } \\
\text { "Project based learning is important }\end{array}$ \\
\hline
\end{tabular}


Table 7.3 (continued)

\begin{tabular}{|c|c|c|}
\hline Category & Subcategory & Statements \\
\hline & & $\begin{array}{l}\text { in every entrepreneurship education } \\
\text { field as there are so many changing } \\
\text { items in the enterprise ecosystem } \\
\text { which can't be handled theoretically, } \\
\text { but only by doing. Social entrepre- } \\
\text { neurship development is about } \\
\text { linking people and organisations, it } \\
\text { is a step-by -step process and can't } \\
\text { be implemented theoretically". R-5 } \\
\text { (STARTERtallinn) }\end{array}$ \\
\hline & $\begin{array}{l}\text { Promotes social entrepreneurship in Esto- } \\
\text { nian society }\end{array}$ & $\begin{array}{l}\text { "Legitimizing the approach of social } \\
\text { entrepreneurship in the society" R-4 } \\
\text { (stories for impact organization) } \\
\text { "Helps to promote social entrepre- } \\
\text { neurship in Estonian society" R-3 } \\
\text { (Võru municipality) }\end{array}$ \\
\hline
\end{tabular}

innovative development projects in the field to make the entrepreneurial contribution to the SE field obvious beside the traditional educational and research profile.

The SEMA program's project-based learning model can offer lessons for other universities. For example, the number of traditional classroom hours has to be significantly smaller as in a traditional academic setting as there needs to be more space for the development of the project in practice. There should be a clear framework for the intellectual property rights between the university, the students and the third parties with contracts in place. Communication rules especially for social and mainstream media should be agreed in advance between all parties. In terms of the physical infrastructure, the traditional classroom setting does not support any project work and there is a need for more dynamic infrastructure allowing teamwork and supportive digital media tools. The administrative personnel should be well informed about the needs and requirements of the project-based learning to be able to accommodate it in administrative support such as making course schedules and calculating workload and hours of lecturers/mentors. A lot of the project work will happen outside the university premises and therefore this requires coordination in planning course schedules for students and allocating more time for teamwork and discussions. Although, project-based learning requires a structured framework, it would also enable giving freedom to students to decide how to implement the project, take risks and mitigate them and adjust to the changes. This will then teach them critical thinking, independence, and key entrepreneurial attributes. However, Estonia is in the process of establishing a social enterprise ecosystem which could flourish with sufficient political support, start-up incubation and support structures. This development could provide credible and sustainable solutions to societal problems, increasing public confidence in social enterprises and relieving pressure on stretched public services. 
It can be said that HEIs play an important role in the development of social entrepreneurship. They educate people who are expected to establish their social enterprises. HEIs can also transfer knowledge across the partnership networks with their academic skills. The Tallinn University SEMA program contributes to SE field development by organizing social hackathons and helping less-empowered groups in remote areas in Estonia. By drawing examples and learning from international networks, the SEMA program's activities produce new knowledge and initiate social enterprises which fit regional needs and expectations. Additionally, SEMA promotes cooperation and establishes linkages between organizations from different sectors. The SEMA program is helping Tallinn University move forward as an entrepreneurial university and as a direct contributor to social entrepreneurship. However, it is still questionable to what extent HEIs could be viewed as innovators and entrepreneurial actors themselves. Due to the path dependency of HEIs, it takes a long time to move from a traditional academic institution into an entrepreneurial university. In case the HEIs want to make the entrepreneurial contribution to the SE field beside traditional teaching and research, they need to focus more on spin-offs, patents and innovative development projects. HEIs need to be increasingly prepared to deploy their resources in trans-disciplinary, collaborative, and innovative ways to address social problems in communities.

Acknowledgments The work is conducted within the framework of COST Action CA 18236 "Multi-disciplinary Innovation for Social Change".

\section{References}

Ajujaht accelerator. (2021). Ajujaht business idea competition and accelerator in Estonia. Accessed Jan 15, 2021, from https://www.ajujaht.ee/en/

Audretsch, D. B., Hülsbeck, M., \& Lehmann, E. E. (2012). Regional competitiveness, university spillovers, and entrepreneurial activity. Small Business Economics, 39(3), 587-601.

Bazan, C., Gaultois, H., Shaikh, A., Gillespie, K., Frederick, S., Amjad, A., . . Belal, N. (2020). A systematic literature review of the influence of the university's environment and support system on the precursors of social entrepreneurial intention of students. Journal of Innovation and Entrepreneurship, 9(1), 4. https://doi.org/10.1186/s13731-020-0116-9

Benneworth, P., \& Cunha, J. (2015). Universities' contributions to social innovation: Reflections in theory \& practice. European Journal of Innovation Management, 18(4), 508-527. https://doi. org/10.1108/EJIM-10-2013-0099

Blumenfeld, P., \& Krajcik, J. S. (2006). Project-based learning. In R. K. Sawyer (Ed.), The Cambridge handbook of the learning sciences (pp. 333-354). Cambridge University Press.

British Council. (2016). Social enterprise in a global context. The role of higher education institutions. Plymouth University. Accessed Oct 16, 2020, from https://www.britishcouncil. org/sites/default/files/social_enterprise_in_a_global_context_-_the_role_of_heis_british_coun cil_0.pdf

Budyldina, N. (2018). Entrepreneurial universities and regional contribution. International Entrepreneurship and Management Journal, 14(2), 265-277.

Cagarman, K., Kratzer, J., \& Osbelt, K. (2020). Social entrepreneurship: Dissection of a phenomenon through a German lens. Sustainability, 12(18), 7764. 
Changemakers academy. (2021). Changemakers academy programme. Accessed Feb 15, 2021, from https://www.changemakers.ee/

Cinar, R. (2019). Delving into social entrepreneurship in universities: Is it legitimate yet? Regional Studies, Regional Science, 6(1), 217-232.

CoSIE project. (2021). Co-Creation of service innovation in Europe. Accessed Jan 15, 2021, from https://cosie.turkuamk.fi/cosie/

Creswell, J. W. (2009). Research design: Qualitative and mixed methods approaches. Sage Publications.

Defourny, J., \& Nyssens, M. (2012). The EMES approach of social enterprise in a comparative perspective (No. UCL-Université Catholique de Louvain). European Research Network.

Domanski, D., Anderson, M., \& Janz, S. (2019). Bridging the gap between academia and practice: Social innovation through knowledge exchange. In Conference paper presented at the 11th ISIRC Conference in Glasgow (pp. 2-4).

European Commission. (2020). Social enterprises and their ecosystems in Europe-comparative synthesis report. Accessed Jan 15, 2021, from http://www.socialenterprisebsr.net/wp-content/ uploads/2020/11/Social-enterprises-and-their-ecosystems-in-Europe.-Comparative-synthesisreport.-Executive-Summary.pdf

Eurostat. (2015). Social protection statistics. Accessed Feb 15, 2021, from https://ec.europa.eu/ eurostat/statistics-explained/index.php?title=Social_protection_statistics\#Per_capita_expendi ture_on_social_protection_and_expenditure_as_percentage_of_GDP

García-González, A., \& Ramírez-Montoya, M. S. (2019). Higher education for social entrepreneurship in the quadruple helix framework: Co-construction in open innovation, in Proceedings of the International Conference Proceeding Series, (New York, NY: ACM), 925-929.

García-González, A., \& Ramírez-Montoya, M. S. (2021). Social entrepreneurship education: Changemaker training at the university. Higher Education, Skills and Work-Based Learning.

Gillham, B. (2000). Case study research methods continuum. New York.

Goddard, J., Hazelkorn, E., \& Vallance, P. (2016). The civic university: The policy and leadership challenges. Edward Elgar Publishing.

Good Deed Foundation Impact Fund. (2021). Venture philanthropy fund in Estonia. Accessed Jan 19, 2021, from https://www.heategu.ee/en

Junior achievement Estonia. (2021). Junior Achievement Estonia program. Accessed Jan 17, 2021, from http://oldwww.ja.ee/index.php?page $=74 \&$

Kaiser, K. (2009). Protecting respondent confidentiality in qualitative research. Qualitative Health Research, 19(11), 1632-1641.

Kim, M., \& Fuessel, A. (2020). Leadership, Resilience, and Higher Education's Promise. Accessed Feb 15, 2021, from https://ssir.org/articles/entry/leadership_resilience_and_higher_educations_ promiseAfbio-footer

Kirby, D. A., Guerrero, M., \& Urbano, D. (2011). The theoretical and empirical side of entrepreneurial universities: An institutional approach. Canadia Journal of Administrative Sciences, 28 (3), 302-316.

Kumari, R., Kwon, K. S., Lee, B. H., \& Choi, K. (2020). Co-creation for social innovation in the ecosystem context: The role of higher educational institutions. Sustainability, 12(1), 307.

National Foundation of Civil Society. (2021). Civil society fund in Estonia. Accessed Jan 17, 2021, from https://www.kysk.ee/impact

Nula incubator. (2021). Nula development programme. Accessed Jan 17, 2021, from https://nula. kysk.ee/en

OECD. (2020), "Boosting social entrepreneurship and social enterprise development in Estonia: In-depth policy review", OECD Local Economic and Employment Development (LEED) Papers, No. 2020/02, OECD Publishing, Paris, Accessed Jan 17, 2021, from https://doi.org/ $10.1787 / 8$ eab0aff-en 
Olo, D. P., Correia, L., \& da Conceição Rego, M. (2020). The Main challenges of higher education institutions in the 21st century: A focus on entrepreneurship. In Examining the role of entrepreneurial universities in regional development (pp. 1-23). IGI Global.

Paunescu, C., \& Cantaragiu, R. (2013). The social role of university entrepreneurship. In Strategic role of tertiary education and technologies for sustainable competitive advantage (pp. 103-119). IGI Global.

Păunescu, C., Drăgan, D., Cantaragiu, R., \& Filculescu, A. (2013). Towards a conceptualization of social entrepreneurship in higher education. The International Journal of Management Science and Information Technology (IJMSIT), 10(Dec), 51-69.

Pugh, R., Lamine, W., Jack, S., \& Hamilton, E. (2018). The entrepreneurial university and the region: What role for entrepreneurship departments? European Planning Studies, 26(9), $1835-1855$.

Reimann, Katri-Liis (2019). Social enterprises and their ecosystems in Europe Country report: Estonia. https://doi.org/10.2767/279418.

Roslan, M. H. H., Hamid, S., Ijab, M. T., \& Bukhari, S. (2019, December). Social entrepreneurship learning model in higher education using social network analysis. In Journal of Physics: Conference Series (Vol. 1339, No. 1, p. 012029). IOP Publishing.

Sánchez-Barrioluengo, M., \& Benneworth, P. (2019). Is the entrepreneurial university also regionally engaged? Analysing the influence of university's structural configuration on third mission performance. Technological Forecasting and Social Change, 141, 206-218.

Social Entrepreneurship incubator. (2021). An online incubation program. Accessed Jan 18, 2021, from https://www.seincubation.com/about

Social entrepreneurship study program. (2021). Social Entrepreneurship Master's program of Tallinn University. Accessed Jan 19, 2021, from https://www.tlu.ee/en/yti/socialentrepreneurship\#course-outline

Starter Tallinn program. (2021). Business idea development program. Accessed Jan 18, 2021, from https://starteridea.ee/startertallinn/

Tallinn University. (2020). Development plan 2020-2022. Accessed Jan 15, 2021, from https:// www.tlu.ee/en/development-plan-2020-2022

Thomas, E., \& Pugh, R. (2020). From 'entrepreneurial'to 'engaged'universities: Social innovation for regional development in the global south. Regional Studies, 54(12), 1631-1643.

Toros, K., Kangro, K., Lepik, K. L., Bugarszki, Z., Sindi, I., Saia, K., \& Medar, M. (2020). Co-creation of social services on the example of social hackathon: The case of Estonia. International Social Work. https://doi.org/10.1177/0020872820904130.

Trippl, M., Sinozic, T., \& Lawton Smith, H. (2015). The role of universities in regional development: Conceptual models and policy institutions in the UK, Sweden and Austria. European Planning Studies, 23(9), 1722-1740.

Urbano, D., \& Guerrero, M. (2013). Entrepreneurial universities: Socioeconomic impacts of academic entrepreneurship in a European region. Economic Development Quarterly, 27(1), $40-55$.

Volkman, C., Tokarski, K., \& Ernst, K. (2012). Social entrepreneurship and social business. An introduction and discussion with case studies. Gabler.

Volkmann, C., Goia, S. I., \& Hadad, S. (2018). Social entrepreneurship across the European Union: An introduction. In Doing business in Europe (pp. 213-234). Springer.

Voorberg, W. H., Bekkers, V. J., \& Tummers, L. G. (2015). A systematic review of co-creation and co-production: Embarking on the social innovation journey. Public Management Review, 17(9), 1333-1357.

Yin, R. K. (2003). Case study research: Design and methods (3rd ed.). Sage.

Yin, R. K. (2009). How to do better case studies. The SAGE handbook of applied social research methods, 2, 254-282. 
Katri-Liis Lepik, PhD is Associate Professor of Management at Tallinn University, Estonia. She is a lecturer in the global Master's programme of Social Entrepreneurship and a mentor in the online Social Entrepreneurship Incubation Program. Katri-Liis is the Chair of the international COST network "Multi-disciplinary innovation for social change" covering 40 countries. Having worked for public, private and non-profit sector, she possesses competences relevant for international collaboration and management consultancy. Katri-Liis is a board member of The Skill Mill Limited-an award-winning Social Enterprise dedicated to the employment of young ex-offenders by providing environmental maintenance services in the UK using Social Impact Bonds. Her research interests focus on social entrepreneurship, public sector and social innovation as well as quadruple helix cooperation.

Audronė Urmanavičienė holds a $\mathrm{PhD}$ in Management Science. She is a social entrepreneurship lecturer at the School of Governance, Law and Society, Tallinn University (Estonia). Her PhD thesis (2019) was on social impact assessment of work integration social enterprises in Baltic states. Audrone is the Communication officer for COST action 18236 "Multi-Disciplinary Innovation for Social Change". Her research interests include social enterprise, social impact and social-impact assessment.

Open Access This chapter is licensed under the terms of the Creative Commons Attribution 4.0 International License (http://creativecommons.org/licenses/by/4.0/), which permits use, sharing, adaptation, distribution and reproduction in any medium or format, as long as you give appropriate credit to the original author(s) and the source, provide a link to the Creative Commons license and indicate if changes were made.

The images or other third party material in this chapter are included in the chapter's Creative Commons license, unless indicated otherwise in a credit line to the material. If material is not included in the chapter's Creative Commons license and your intended use is not permitted by statutory regulation or exceeds the permitted use, you will need to obtain permission directly from the copyright holder.

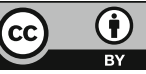

